Feature Article

\title{
Sandalwood Research: A Global Perspective
}

\author{
S.M.C.U.P. Subasinghe \\ Department of Forestry and Environmental Science, University of Sri Jayewardenepura, Nugegoda, \\ Sri Lanka
}

\section{Introduction}

Sandalwood is a commercially and culturally important plant species belonging to the family Santalaceae and the genus Santalum. Sandalwood oil extracted from the heartwood has been used for perfumery, medicinal, religious and cultural purposes over centuries of years. In addition to oil, the wood and its powder are used for religious, cultural and medicinal purposes especially in the Asian and Arab regions. There are around 18 sandalwood species belonging to the genus Santalum which are; $S$. freycinetianum, $S$. haleakalae, $S$. ellipticum, $S$. peniculatum, $S$. pyrularium, $S$. involutum, S. boninese, $S$. insulare, $S$. austrocaledonicum, $S$. yasi, $S$. macgregorii, S. accuminatum, S. murrayanum, S. obtusifolium, S. lanceolatum, S. fernandezianum, S. salicifolium and S. spicatum. All the sandalwood species are identified as obligate wood hemi-parasites which means they absorb certain nutrients such as phosphates and nitrates from the host trees via root connections called haustoria.

The global distribution of the sandal family is between 30 degrees $\mathrm{N}$ and 40 degrees $\mathrm{S}$ from Indonesia in West to Juan Fernandez Island in the north to New Zealand in the South. These species are mainly found in India, Indonesia, Australia, Timor, Hawaii etc. Out of the 18 species mentioned above, about 6 species can be found in Hawaii Islands which shows the highest sandalwood diversity.

The main reason for the economic and cultural value of sandalwood is the oil contained in the sandalwood timber, mainly in the heartwood. Heartwood oil content varies, however, widely between species and even within species. S. album known as Indian sandalwood is renowned for its oil, which is highly rated for its sweet, fragrant, persistent aroma and the fixative property which is highly demanded by the perfume industry. Jain et al (2003) reported that heartwood of S. album was priced at 12 lakhs of Indian rupees per tonne and oil was priced at 22,000 Indian rupees per $\mathrm{kg}$. However, the prices are highly depended on the quality. Due to the high value of oil and timber, $S$. album has been central among all sandalwood species in the aspect of research.

Currently most of the world demand of sandalwood is supplied from Australia using S. spicatum known as Australian sandalwood. Due to the high value and the demand, there is a growing attention at present in establishing sandalwood, especially $S$. album plantations in the tropical region including Sri Lanka over the most demanding other forest plantation species, i.e., teak, mahogany etc. by the private sector plantation companies, due to the large domestic demand and the existing high demand. In accordance with that, there is a trend in sandalwood plantation establishment in Australia, India, Sri Lanka, China, and Fiji since recently. However, the plantation sector lacks the information on establishing sandalwood plantations, which is identified as a great risk when considering their profit maximising goal. Without the information such as nursery techniques, host suitability, plantation establishment, growth rates and oil characteristics, managers of sandalwood plantations might therefore face difficulties in achieving the expected outcomes.

*Correspondence: upuls@sjp.ac.lk

Tel: +94-112758421, Fax: +94 112803470

ISSN 2235-9370 Print / ISSN 2235-9362 Online (C2013 University of Sri Jayewardenepura 


\section{Sandalwood research at global perspective}

Scientific research on sandalwood started in the period of 1940-50. It was commenced with the silvicultural trials because that was the time the sandalwood, especially $S$. album was started to introduce to countries like Australia from its native range of existence. From that era, research evolves from silvicultural studies, ecological studies to oil chemistry and genetics. Most of such researches were funded by the different research institutes and different governments due to the importance of having new information on these species. However, according to the reputed sandalwood research devotees, still there are areas to be further explored in sandalwood research. The following sections analyse the researches conducted on different areas of sandalwood in the past.

\subsection{Ecological studies}

Most of the ecological distribution and population studies have been conducted for the sandalwood species growing in the Australian and Pacific regions of the world. The reason may be due to the interest of the scientists living in the same regions and USA. The other reason of having many studies completed in the Pacific region could be the presence of the threatened or very rare sandalwood species in that particular region, especially in Hawaii Islands. Comparatively a little amount of ecology and distribution research has been done on $S$. album, commercially the most important species of all sandalwoods which is naturally growing in India, Si Lanka and Indonesia.

Some of the sandalwood ecology and population studies were conducted on regional basis such as the study of Sinha (1991) on sandalwood in Bundelkhand Forest Division, Uttar Pradesh of India, $S$. album profile study conducted in Pondicherry region of India by Balachandran and Kichenamourthy (2007), the dendrological research on S. paniculatum in the dry montane forests of Mauna Loa of Hawaii Island conducted by Senock (2012), and sandalwood resources and its management in East Nusa Tenggara, Timor Province of Indonesia by Septiani (2012). A large amount of ecological research of sandalwood species have been conducted in more broader manner, e.g., distribution and ecology of $S$. insulare by Butaud (2004); distribution and status of sandalwood in Hawaii by Stemmermann (1990). The distribution and ecology research were not conducted on $S$. album in Sri Lanka which is an important area to study because of the recent finding of growing this species beyond the mid-country intermediate zone where known to produce good quality sandalwood.

\subsection{Silviculture and propagation}

Silviculture research of sandalwood perhaps has the longest history among all types of sandalwood research conducted in the past. S. album was frequently studied in this aspect mainly because this species was tried to introduce to many new locations or countries as its oil has the highest value among all sandalwood species. Seed germination was given a priority among the silvicutlure studies by many researchers around the world, e.g., Doran (2012) Annupurna et al (2006), Gamage et al (2010), Nagini and Shrimathi (1985). The reason of this was due to the prolonging dormancy period and low germination rates of sandalwood seeds. Prof. J.E.D. Fox was one of the pioneers to study the silviculture and host species of S. album in the world (Fox, 2000; Brand et al, 1993; Struthers, 1986). Following his work, many researches were conducted in the recent past on the effect of different host species in different localities, e.g., Ananthapathmanabha (2012), Subasinghe and Hettiarachchi (Unpublished), Nagaveni and Vijayalakshmi (2003). Those studies conducted on S. album showed a variation of results. However, the most commonly identified suitable hosts by the above mentioned researches were Pongamina pinnata, Casuarina equestifolia and Sesbenia grandiflora. In 2004, Brand et al conducted a study on the effect of Acacia host species on S. spicatum growing in Australia and they found out A. saligna and A. acuminate as the best species. However, those studies should be further researched to find out the most suitable species for different climatic regions. 
There was an interest among the researchers especially in the Pacific region from the past to form hybrids of sandalwood. These studies mainly focused on producing higher contents of sandalwood oils with a better survival rate. According to Ananthapathmanabha (2012), S. album x S. yasi hybrid called F1 shows a more vigour and an average of $7 \%$ oil which is almost impossible to obtain from the parent trees. In $1998 \mathrm{McComb}$ and Jones attempted to form a hybrid using S. album and S. spicatum using in vitro culture method. A trial established in Hawaiian Ethnobotanical Garden of Honolulu in 1959 in hybridisation of $S$. frecinetianum and $S$. album is still present. However, there is a debate on the quality of the oil produced by those hybrids and further, there is a fear among the top level sandalwood merchants in entering low quality sandalwood oils by the hybrid species to the market.

Biotechnological approaches were also attempted to propagate $S$. album in mass scale by many scientists. Bapat and Rao (1998) and Sanjaya et al (1998) conducted detailed studies on that aspect in India.

\subsection{Pests and diseases of sandalwood}

The pests and diseases of sandalwood were mainly studied by Indian scientists on S. album. Sundararaj and Muthukrishnan (2011), Sundararaj (2012) identified 92 sap-suckers, 60 defoliators, 6 stem borers, 5 bark and dead wood feeders, 3 dry wood feeders, 3 seed feeders and 1 flower feeder on $S$. album growing in India. However, among those pests, only a few are harmful. In addition, Remadevi (2012) has conducted research on the bio-deterioration of sandalwood logs by termites. Bio-deterioration severely lowers the log quality. Especially for the ones that are used for carvings. She further found that, the light traps can effectively be used against those termites. In addition, a phytoplasma like disease named spike disease has also been identified at the nursery stage of S. album (Gowda and Narayana 1998; Rangaswami, 1998). However, a limited number of studies have been conducted on the other sandalwood species on pests and diseases.

\subsection{Variations of sandalwood oil contents}

The values of the oils are ranked in the world market of sandalwood as shown in the Table 1 . The rest of the species produce low or no value in the oils or the other oil producing sandalwood species such as $S$. haleakalae became very rare.

Table 1: Commercially valuable sandalwood species and their natural distribution

\begin{tabular}{llll}
\hline Rank & Scientific name & Vernacular name & Natural distribution \\
\hline 1 & S. album & Indian sandalwood & India, Indonesia, Sri Lanka \\
2 & S. yasi & & Fiji, Niue, Tonga \\
3 & S. asutrocaledonicum & Vanuatu sandalwood & New Caledonia, Vanuatu \\
4 & S. macgregorii & & Papua New Guinea, Indonesia \\
5 & S. spicatum & Austrian sandalwood & Australia \\
6 & S. lanceolatum & Northern Sandalwood & Australia \\
\hline
\end{tabular}

The most important concern among the sandalwood growers is therefore the oil quantity that can be obtained from a harvested tree. This amount usually expressed as a weight percentage to the amount of sandalwood timber used to extract the oil. Most studies have been conducted on S. album in this regard in the past because it produces the most important oil among all sandalwood species.

The study conducted by Doran et al (2005) on young S. yasi and S. album growing in the Pacific region showed a low amount of oil in both species due to low formation of heartwood at the early years. However, the F1 hybrid formed by $S$. yasi x $S$. album showed a high vigour and thereby comparatively a high amount of oil content. Xiaojin et al (2011) found out the variation of oil content of 6 year old $S$. album growing in Gaoyao, Guangdong province, South China from $0.64 \%$ to $1.78 \%$. 
The studies conducted in Sri Lanka by Subasinghe et al (2013) on S. album in Sri Lanka showed a higher variation of oil content. They, however, found significantly high oil content, i.e., 6.36\% in some trees tested. It is encouraging for the sandalwood growers in Sri Lanka to find the sandalwood trees with high oil contents. This study is conducted further in larger extents to identify more variations and the reasons under the funding of the National Research Council of Sri Lanka (Subasinghe and Hettiarachchi, unpublished).

In addition to those studies, many other researchers, e.g., Doran et al (2005), Joulain et al (2012), Jain et al. (2003) found a high variation of oil between individuals of similar size and growing in the same area. These variations were, however, not properly explained by the authors and therefore it can be suspected that the genetic factors may play a significant role in oil formation. In addition it may also be due to the climatic and topographical factors.

\subsection{Chemistry of sandalwood oil}

Sandalwood oil known as santalol is the most important part of the sandalwood tree. It contains a larger number of chemical compounds. However, the specific aroma of sandalwood oil is produced mainly by two chemical compounds known as alpha and beta santalols. Therefore in order to maintain the oil quality, ISO standards have been formulated by ISO 3518:2002 for S. album and S. spicatum as given in the Table 2 for those two compounds. The rest of the commercially valuable sandalwood species should follow the levels of S. album.

Table 2: ISO standards given for alpha and beta santalol levels

\begin{tabular}{llr}
\hline & \multicolumn{2}{c}{ ISO standard } \\
\cline { 2 - 3 } Species & Alpha \% & Beta $\%$ \\
\hline S. album & $41.0-55.0$ & $41.0-55.0$ \\
S. spicatum & $15.0-25.0$ & $5.0-20.0$ \\
\hline
\end{tabular}

In accordance with the figure given in the Table 2, many researches have been conducted on the quality of oil and its variations between the individuals of the same species, between species, locations, tree size and oil extraction method etc. However, according to the results conducted in oil content variations the past, it was evidenced that the oils of the different sandalwood species may not always in the region of the expected santalol levels. The research conducted especially on S. album, S. spicatum, A. yasi, S. austrocaledonicum etc. by Hettiarachchi (2008), Moniodius (2012), Day (2012), Brand et al., (2006), Xiaojin et al., (2011) indicate wide range of alpha and beta santalol levels over the expected ranges due to unknown or unidentified causes. In addition, researches have been conducted on Farnesol levels of sandalwood oils mainly because it has been identified as an allergy causing substance of the sensitive skins (Hettiarachchi 2008, Joulian 2012, Subasinghe et al., 2013).

The unknown causes of the variation of sandalwood oil compounds show the importance of conducting further research on sandalwood oil formation and the external and internal parameters that may affect its quality. However, there may be a strong influence of genetic characteristics to the quality parameters of sandalwood oil as suspected by Subasinghe and Hettiarachchi (Unpublished) because they noticed unexplainable oil quality variations of $S$. album trees of similar size growing under very similar soil and climatic conditions.

\subsection{Genetics}

Sandalwood genetics studies became more popular in the near past with the acceleration of such research by Australian and American scientists. DNA bar-coding has been done for many species and frequent uses of micro-satellites were common in those researches. Harbaugh (2008) used these methods for differentiating sandalwood species and individuals and according the results, she formed a theory on the origin of all sandalwood species in Australia. DNA Cloning has also been done for protein compounds 
by Sita and Bhattacharya in 1997 for S. album. In 1998, Jain et al also studied on genetic variations of $S$. album provenances of India. Genetic mapping of Indian sandalwood resources were done by NageshwaraRao in 2012. Jones et al $(2006,2008,2011)$ conducted detailed genetic studies on $S$. album in Australia. Their studies were mainly focused on DNA isolation and fragrance biosynthesis of $S$. album.

\section{Conservation status of sandalwood species}

Sandalwood is recognised worldwide as one of the most valuable commercial tree species. Due to the over harvesting from the wild and lack of sufficient plantation establishment, sandalwood resource declined worldwide from the past in rapid manner. For example, recent data on production of sandalwood in India show a declining trend. India's sandalwood production dropped from 4,000 MT heartwood per year in the 1950 s to a mere $500 \mathrm{MT}$ in 2007 as against the global annual demand of about 5,000 to 6,000 MT wood and around 100 to 120 MT oil (Dhanya et al, 2010). In addition to that, grazing and land conversion to agriculture crops such as sugar cane and pine apple have caused the sandalwood resource decline especially in Australia and Hawaii. According to Harbaugh (2008), one sandalwood species has already been extinct due to over harvesting and many of others like $S$. haleakele are in highly threatened situation.

Due to the facts mentioned above, the governments like Australia, Hawaii, India, New Caledonia, and Sri Lanka have taken actions against illegal harvesting and formulated rigid policies in conservation of the sandalwood resources. Joining with the governments, different organizations such as International Sandalwood Foundation operated from United States, Iliahi Foundation of Sandalwood of Hawaii promote research and take actions in conservation of sandalwood species in the world.

India has realised the value of sandalwood trade and at the same time, to protect the wild grown sandalwood resources, Karnataka and Tamil Nadu provinces of India changed the existing policies to promote sandalwood growing in private lands. Realising the flaws in sandal policy which endangered the species, Government of Karnataka came up with amendment to Karnataka Forest Act in 2001 to encourage private domestication of sandalwood as means to conserve and enhance the status of this resource (Dhanya et al, 2010). The amendment gave landowners legal right to trees on their land and made them eligible to receive full value on extraction. Shortly, Tamil Nadu followed the same path and with the Tamil Nadu Forest (Amendment) Act of 1998 in 2002, the landowners were given the right to trees (Dhanya et al, 2010).

\section{Final remarks}

Research has been conducted on various species of sandalwood on many aspects such as ecology, silviculture, plantation establishment, pests and disease, genetics etc. in different parts of the world. However, the rate of plantation establishment has still not promising in sandalwood growing countries other than for $S$. album cultivation in Australia. Therefore the information generated by different researchers should come to a central point so that everybody can use them in plantation establishment and conservation. In addition, more research are needed in developing methods to identify the genuine sandalwood oils from the fake products as the present market is flooded with such low quality artificial oils deliberately manufactured to capture the sandalwood market. In addition, more research should be conducted on the oil quality of hybrid sandalwood varieties although some hybrids such as $S$. album x $S$. yasi show promising improvements in vigour and oil contents.

The reasons for the sandalwood oil content variation are still not properly known and therefore it is vital to identify the high oil producing trees especially $S$. album which is intensively used for sandalwood plantation establishment in Australia, China and Sri Lanka. Such high oil yielding trees can be used as mother trees or parents so that the next generations can be formed by using them. 
In addition to that, it is the time that the scientists of different disciplines should work together to achieve the better outcomes of sandalwood research and therefore this paper proposed to enhance the collaborative research work between different universities of different countries so that the better outputs can be achieved.

\section{References}

Ananthapadmanabha, H.S. 2012. Indian sandalwood market trend production. Proceedings of International Sandalwood Symposium, 21-24 October, 2012, Honolulu, Hawaii

Annupurna, D. Rathore, T.S., Joshi, G. 2006. Modern nursery practices in the production of quality seedlings of Indian sandalwood. Journal of Sustainable Forestry 22:33-35

Balachandran, N., Kichenamourthy, S. 2007. Profile of natural stands of Santalum album L. in the Pondicherry region, India. Sandalwood Research Newsletter 22:4-9

Bapat, V.A., Rao, P.S. 1998. Biotechnological approaches for propagation of sandal (Santalum album L.). (In) Sandal and its products, A.M. Radomiljac, H.S. Ananthapadmanabha, RM. Welbourn and K. Salyanarayana Rao (eds), Australian Centre for International Agricultural Research Canberra, 42-44

Brand, J.E., Fox, J.E.D, Effendi, M. 1993. Variation in seed size and germination of Santalum album L. populations in NTTS Timor. Santalum 12:37-49

Brand J.E., Jones, P., Donovan, O. 2004. Current growth rates and predicted yields of sandalwood (Santalum spicatum) grown in plantation in south-western Australia. Sandalwood Research Newsletter 19:4-7

Brand, J.E., Kimber, P., Streatfield, J. 2006. Preliminary analysis of Indian sandalwood (Santalum album L.) oil from a 14-year-old plantation at Kununurra, Western Australia Sandalwood Research Newsletter 21:1-3

Butaud, J.F. 2004. Santalum insulare (Bertero ex A. DC.): Distribution and ecology. Sandalwood Research Newsletter 19:1-4

Day, J. 2012. Musings of sandalwood oil distiller. Proceedings of International Sandalwood Symposium, 21-24 October, 2012, Honolulu, Hawaii

Dhanya, B., Viswanath, S., Purushothman, S. 2010. Sandal (Santalum album L.) conservation in southern India: A review of policies and their impacts Journal of Tropical Agriculture 48(1-2):1-10, 2010

Doran, J. 2012. Review of Santalum album seed pre-germination treatments with a focus on low cost methods. Proceedings of International Sandalwood Symposium, 21-24 October, 2012, Honolulu, Hawaii

Doran, J.C., Thomson, L., Brophy, J.J., Goldsack, B., Bulai, P., Faka'osi, T., Mokoia, T. 2005. Variation in heartwood oil composition of young sandalwood trees in the south Pacific (Santalum yasi, S. album and F1 hybrids in Fiji, and S. yasi in Tonga and Niue). Sandalwood Research Newsletter 20:3-7

Fox, J.E.D., 2000. Sandalwood: the royal tree. Biologist, 47:31.

Gamage, Y.M.M., Subasinghe, S.M.C.U.P., Hettiarachchi, D.S., Change of seed germination rate with storage time of Santalum album L. (Indian sandalwood) seeds. Proceedings of the 15th International Annual Forestry and Environment Symposium, 26-27 November, 2007, University of Sri Jayewardenepura, Sri Lanka

Gowda, A.N.S., Narayana, R., 1998. In-vitro comparative morphogenetic studies of normal and spikediseased tissues of sandal (Santalum album L.). (In) Sandal and its products, A.M. Radomiljac, H.S. Ananthapadmanabha, RM. Welbourn and K. Salyanarayana Rao (eds), Australian Centre for International Agricultural Research Canberra, 167-174

Harbaugh, D. 2006. Molecular and morphological phylogeny of sandalwoods: Insights for biogeography and taxonomy. Sandalwood Research Newsletter 21:8.

Hettiarachchi, D.S. 2008. Volatile oil content determination in the Australian sandalwood industry: Towards a standardised method. Sandalwood Research Newsletter 23:1-4. 
Jain, S.H., Angandi, V.G., Shankaranarayana, K.H., Rajeevalochan, A.N., Theagarajan, K.S., Ragaswami, C.R. 1998. Identification of provenances of sandal in India for genetic conservation. (In) Sandal and its products, A.M. Radomiljac, H.S. Ananthapadmanabha, RM. Welbourn and K. Salyanarayana Rao (eds), Australian Centre for International Agricultural Research Canberra, 117-120

Jain, S.H., Angandi, V.G., Shankaranarayana, K.H., Ravikumar, G. 2003. Relationship between girth and percentage of oil in sandal provenances. Sandalwood Research Newsletter 18:4-5

Jones, C.G., Ghisalberti, E.L., Plummer, J.A., Barbour, E.L. 2006. Quantitative cooccurance of sesquiterpenes: a tool for elucidating their biosynthesis in Indian Sandalwood, Santalum album. Phytochemistry, 67(22):2463-2468.

Jones, C.G., Keeling, C.I., Ghisalberti, E.L., Barbour, E.L., Plummer, J.A., Bohlmann, J. 2008. Isolation of cDNAs and functional characterisation of two multiproduct terpene synthase enzymes from sandalwood, Santalum album L. Archives of Biochemistry and Biophysics, 477(1):121-30.

Jones, C.G., Moniodis, J., Zulak, K.G., Scaffidi, A., Plummer, J.A., Ghisalberti, E.L., Barbour, E.L., Bohlmann, J. 2011. Sandalwood fragrance biosynthesis involves sesquiterpene synthases of both the terpene synthase (TPS)-a and TPS-b subfamilies, including santalene synthases. The Journal of Biological Chemistry, 286 (20):17445-17454.

Joulain, D., Nengone, S.N., De Guahma, D., dit Lyo, L. 2012. New insights into the qualitative and quantitative analytical chemistry of sandalwood essential oils New Caledonia, France. Proceedings of International Sandalwood Symposium, 21-24 October, 2012, Honolulu, Hawaii

McComb, J.A., Jones, M.G.K. 1998. Interspecific hybridisation between Santalum album and $S$. spicatum. (In) Sandal and its products, A.M. Radomiljac, H.S. Ananthapadmanabha, RM. Welbourn and K. Salyanarayana Rao (eds), Australian Centre for International Agricultural Research Canberra, $36-41$

Moniodius, J. 2012. Chemical diversity and biosynthesis of Australian sandalwoods' essential oil. Proceedings of International Sandalwood Symposium, 21-24 October, 2012, Honolulu, Hawaii

Nagaveni, H.C., Vijayalakshmi, G. 2003. Growth performance of sandal (Santalum album L.) with different host species. Sandalwood Research Newsletter 18, 1-4.

Nageswara-Rao, M. 2012. Mapping sandal genetic resources in India: Threats and conservation strategies. Proceedings of International Sandalwood Symposium, 21-24 October, 2012, Honolulu, Hawaii

Nagini, H.C., Shrimathi, A.R., 1985. Germination capacity of floating \& inking sandal seeds. Indian Forester 111(8):615-618.

Rangaswami, K.T. 1998. Fluorescence Microscopy of sandal affected with spike disease (In) Sandal and its products, A.M. Radomiljac, H.S. Ananthapadmanabha, RM. Welbourn and K. Salyanarayana Rao (eds), Australian Centre for International Agricultural Research Canberra, 181

Remadevi, O.K. 2012. Sandalwood biodeterioration in Indian conditions: Causes, impacts and remedies. Proceedings of International Sandalwood Symposium, 21-24 October, 2012, Honolulu, Hawaii

Sanjaya, Ananthapadmanabha, H.S., Rai, V.R. 1998. In-vitro shoot multiplication from the mature tree of Santalum album L. (In) Sandal and its products, A.M. Radomiljac, H.S. Ananthapadmanabha, RM. Welbourn and K. Salyanarayana Rao (eds), Australian Centre for International Agricultural Research Canberra, 45-49

Senock, R.S. 2012. Status of dendrological research on Santalum paniculatum in the dry montane forests of Mauna Loa in Hawaii Island. Proceedings of International Sandalwood Symposium, 21-24 October, 2012, Honolulu, Hawaii

Septiani, Y. 2012. Sandalwood resources and its management in east Nusa Tenggara Timor Province, Indonesia. Proceedings of International Sandalwood Symposium, 21-24 October, 2012, Honolulu, Hawaii

Sinha, R.L. 1991. Sandalwood in Bundelkh and Forest Division, Uttar Pradesh. Indian Forester 87(10):590-597

Sita, G.L.A., Bhattacharya, A. 1998. cDNA cloning and characterisation of a proline- (or hydroxyproline) rich protein from Santalum album L. (In) Sandal and its products, A.M. Radomiljac, H.S. 
Ananthapadmanabha, RM. Welbourn and K. Salyanarayana Rao (eds), Australian Centre for International Agricultural Research Canberra, 29-35

Stemmermann, L. 1990. Distribution and Status of Sandalwood in Hawaii. Proceedings of the Symposium on Sandalwood in the Pacific 9-11 April, 1990, Honolulu, Hawaii

Struthers, R., Lamont, B.B., Fox, J.E.D., Wijesuriya, S., Crossland, T. 1986. Mineral nutrition of sandalwood (Santalum spicatum) Journal of Experimental Botany 37(9):1274-1284

Subasinghe, S.M.C.U.P., Hettiarachchi, D.S. Unpublished. Establishment of Indian sandalwood (Santalum album) plantations and determination of the variation of oil contents in different geographical regions of Sri Lanka, National Research Council, Sri Lanka.

Subasinghe, U., Gamage, M., Hettiarachchi, D.S. 2013. Essential oil content and composition of Indian sandalwood (Santalum album) in Sri Lanka. Journal of Forestry Research 24(1): 127-130

Sundararaj, R. 2012. Insect pest complexes of Indian sandalwood in areas outside forest and the challenges in its management. Proceedings of International Sandalwood Symposium, 21-24 October, 2012, Honolulu, Hawaii

Sundararaj, R., Muthukrishnan, R. 2011. Population dynamics of some coccids (Coccoidea: Hemiptera) infesting sandal (Santalum album Linn.) in Bangalore, India. Journal of Forestry Research 22(2):259262

Xiaojin, L., Daping, X., Zengjiang, Y., Ningnan, Z., Lijun, Y. 2011. Preliminary analysis of growth and oil composition from a 6-year-old sandal (Santalum album L.) plantation in Gaoyao, Guangdong, south China. Sandalwood research Newsletter 26:1-5 